\title{
REKOGNISI AGAMA LOKAL PRASYARAT MENUJU DEMOKRASI MAJEMUK
}

\author{
Sudarto \\ Pusaka Foundation Padang, mastoto75@gmail.com
}

\begin{tabular}{l|l|l} 
Diterima: 30 Juli 2019 & Direvisi: 29 November 2019 & Diterbitkan: 19 Desember 2019
\end{tabular}

\begin{abstract}
The biggest challenge for plural democracy is how to manage the diversity of its people according to the principles of equality and justice. In this connection, it cannot be denied Indonesia as a plural state is being faced with the maturation of democracy on one side, and the challenges of managing the diversity of its people on the other side. Some of the challenges of pluralism that still occur in Indonesia include: First, there are still many overlapping regulations. Especially regarding the management of religious diversity. Secondly, law enforcers do not provide protection. Mainly related to freedom of religion or belief. Third, although Indonesian people basically live in a pluralistic reality, but in fact the foundation of tolerance of the plural Indonesian society is still relatively fragile. The problem of managing the diversity of religions or beliefs as described above, has an interconnected relationship with the difficulty of presenting the moderation of religions in Indonesia. The question is how to manage the diversity of religions and beliefs according to the principle of equality and fairness, especially for the local belief groups of the archipelago, which in political language is called the flow of trust nomenclature? How is the portrait of the state's treatment of local religious groups? And offers the concept of diversity management which is expected to contribute to reaffirming Indonesia's diversity towards Islamic moderation. Because it cannot be denied, speaking of religious moderation actually speak of religious tolerance amid diversity in high intensity.
\end{abstract}

Keywords: local religion, regulation, diversity management, restructurization.

\begin{abstract}
Abstrak
Tantangan terbesar bagi demokrasi majemuk adalah bagaimana mengelola keberagaman masyarakatnya menurut prinsip-prinsip kesetaraan dan keadilan. Dalam kaitan ini tidak bisa dipungkiri, Indonesia sebagai negara majemuk sedang dihadapkan dengan pematangan berdemokrasi pada satu sisi, dan tantangan mengelola kemajemukan bangsanya pada sisi lainnya. Beberapa tantangan kemajemukan yang masih terjadi di Indonesia antara lain: Pertama, masih banyaknya regulasi tumpang-tindih, khusunya menyangkut tata kelola keberagaman agama. Kedua, para penegak hukum kurang memberikan perlindungan, utamanya terkait dengan kebebasan beragama atau keyakinan. Ketiga, meskipun masyarakat Indonesia pada dasarnya hidup dalam realitas kemajemukan, namun sesungguhnya fondasi toleransinya masyarakat Indonesia yang majemuk itu tergolong masih rapuh. Problem tata kelola keberagaman agama atau keyakinan sebagaimana terurai di atas, memiliki hubungan interkausa dengan sulitnya menghadirkan moderasi agama-agama di Indonesia. Pertanyaannya adalah bagaiman mengelola kembali keberagaman agama dan keyakinan menurut prinsip kesetaraan dan berkeadilan, utamanya bagi kelompok keyakinan lokal nusantara, yang dalam bahasa politik nomenklatur disebut aliran kepercayaan? Bagaimana potret perlakuan negara terhadap kelompok agama lokal? Dan menawarkan konsep pengelolaan keberagaman yang diharapkan dapat berkonstribusi mengukuhkan kembali keberagaman Indonesia menuju moderasi Islam. Karena tidak bisa dipungkiri, bicara moderasi agama tidak
\end{abstract}


sesungguhnya berbicara toleransi agama di tengah keberagaman dalam intensitas yang tinggi.

Kata Kunci: agama lokal, regulasi, pengelolaan keberagaman, restrukturisasi.

\section{PENDAHULUAN}

Bagaimana mungkin kita akan menghadirkan moderasi agama-agama jika praktik intoleransi dan diskriminasi terhadap kelompok agama dan keyakinan berbeda berbeda masih terus terjadi? Dalam konteks ini, meskipun Indonesia telah memproklamirkan diri sebagai negara bangsa (nation state) merdeka sejak 74 tahun yang lalu, namun sekelompok warga negara yang meyakini agama atau kepercayaan warisan leluhurnya masih diperlakukan secara diskriminatif yang cenderung sistematis, terstruktur dan masif? Pemeluk agama lokal diperlakukan seolah tamu di negeri sendiri. ${ }^{1}$ Mereka menjadi obyek penyebaran agama-agama besar sekaligus menjadi sasaran politik penyingkiran (exclusionary politic) oleh elit negara di negeri ini demi dan atas nama konstituen. Tidak cukup cerdaskah kita mengelola keberagaman khususnya agama?

Moderasi agama-agama tidak akan pernah ada tanpa adanya pengakuan yang tulus terhadap realitas keberagaman. Apalagi jika praktik-praktik politik pembedaan yang bersifat diskriminatif melibatkan aktor negara. Berdasarkan penelusuran panjang memahami dinamika dan praktik diskriminasi terhadap agama lokal, dalam konteks Indonesia setidaknya melibatkan empat aktor utama. ${ }^{2}$ Pertama, diskriminasi regulatif melibatkan aktor pemerintah atas nama negara. Pada level ini, negara cq. pemerintah secara sengaja memproduksi berbagai kebijakan yang berdampak diskriminatif terhadap agama lokal.

${ }^{1}$ Sudarto, Religionisasi Indonesia; Sejarah Perjumpaan Agama Lokal dan Agama Pendatang (Jakarta: PT. Gramedia Pustaka Utama, 2016), 130.

${ }^{2}$ Sudarto, Religionisasi Indonesia, 130; Samsul Maarif, Pasang Surut Rekognisi Agama Lelubur dalam Politik. Agama di Indonesia (Yogyakarta: Center for Religious and Cross-culture Studies, 2018), 5.
Misalnya UU No. 1/PNPS/1965 tentang penodaan agama. Pada UU ini menjadikan agama lokal tertuduh sebagai pengacau keamanan. Diperkuat dengan TAP MPR No. IV/MPR 1978 tentang Garis-Garis Besar Haluan Negara (GBHN), Negara secara sengaja mengeliminasi agama lokal dengan berbagai alasan dan stigma.

Kedua, dari kalangan agama-agama besar, utamanya agama-agama Ibrahimi (Abrahamic Religion), yang secara tidak sportif melakukan monopoli definisi agama. Kelompok agama besar yang didukung Negara memberikan batasan apa yang disebut agama dan bukan agama. Monopoli definisi agama inilah yang oleh Daniel Dakhidai disebut sebagai religious discourse atau diskursus agama. ${ }^{3}$ Konsekuensi dari praktik monopolis dalam pendefinisian agama, nasib agama lokal menjadi di ujung tanduk. Karena agama-agama besar menggunakan standar Abrahamic Religion untuk menentukan keyakinan yang masuk kategori agama dan bukan Agama. ${ }^{4}$ Akibatnya agama lokal menjadi tereksklusi di negeri sendiri.

Ketiga, kalangan akademisi dengan pendekatan antropologi-etnografik terlibat melakukan praktik diskriminasi terhadap agama lokal melalui berbagai labeling. Antar lain: agama primitif paganisme, anismisme, dinamisme heidenen, kafir, bahkan merendahkan agama lokal sebagai sampah atau residual factor. Dalam kaitan ini, jika mau sedikit jujur, sebutan agama langit (Samawr) dan Agama bumi (Ardli), pada dasarnya diam-diam

${ }^{3}$ T. S. Sutanto, Merayakan Kebebasan; Bunga Rampai Menyamput 70 Johan Effendi (Jakarta: ICRP dan Kompas, 2013), 117.

${ }^{4}$ J. M. Atkinson, "Religion and Dialogue, The Construction of an Indonesian Minority Religion". Dalam Rita Smith Kipp dan Susan Rogers (eds), Indonesia Religion in Transition (Tucson: The University of Arizona Press, 1978), 177. 
menyimpan nalar degradatif terhadap agamaagama adat dan agama lokal dimanapun. Meskipun kenyataannya jika meminjam analisnya EB. Taylor secara etnografi tidak satupun agama yang tidak primitif dan animis. ${ }^{5}$

Keempat, kalangan media dan dunia hiburan selebritis tidak kalah "sadis" terlibat dalam menstigma agama lokal melalui tayangantayangannya. Liputan "primitive runway" misalnya secara sengaja ataupun tidak telah telah mengkampanyekan bahwa agama lokal sebagai manusia-manusia primitif dan tidak beradab. Banyak media mainstrem menggambarkan komunitas agama lokal di pedalaman dengan pandangan rendak bahkan jijik, utamanya terhadap makanannya.

Di kalangan dunia perfileman misalnya, para pemimpin agama lokal digambarkan sebagai sosok antagonis berhadapan dengan tokoh-tokoh agama yang berperan protagonis dari kalangan kiai/ustadz. Film-film religi sejak 1980-an sebenarnya telah berperan besar dalam memproduksi stigma terhadap agama lokal. Beberapa contoh, film Kafir, film Misteri Gunung Merapi, dan film nasional lainnya yang secara sengaja mengekploitasi praktik-praktik keagamaan komunitas agama lokal sebagai tontonan mistis. Sehingga opini yang terbentuk agama lokal adalah agama klenik ilmu hitam, dukun, kumuh, dan angker. Padahal jika kita menggunakan analisis EB. Taylor, James Frezer dan lainnya, agama-agama besarpun melakukan hal-hal magis, klenik, dan perdukunan dalam logika samanisme.

Perlakuan diskriminatif terhadap agama lokal melahirkan trauma berkepanjangan bagi sebagain warga negara yang setia memeluk agama dan kepercayaan warisan leluhurnya, oleh karena itu jika negara dengan pemeluk Muslim terbesar di dunia ini ingin menghadirkan wajah agama yang moderat, tiada pilihan lain, kecuali mengakui dalam pengertian

${ }^{5}$ Daniel L. Pals, Eight Theories of Religion, Second Edition (New York: Oxford Univerty Press, 2006), 33. politik rekognisi terhadap agama lokal nusantara. Terkait dengan pemilihan agama dan keyakinan, tugas negara adalah menghormati, melindungi, dan memenuhi (to respect, to protect and to fullfil pilihan agama atau kepercayaan setiap warganya tidak lebih dan tidak kurang. Studi ini secara komprehensif menggambarkan bagaimana agama lokal selama ini didiskriminasi oleh negara, sekaligus menawarkan gagasan pengelolaan keberagaman.

\section{KONSTRUKSI AGAMA DI INDONESIA}

Kebijakan politik kehidupan beragama pada era kemerdekaan Indonesia baik zaman Orde Lama maupun Orde Baru, hingga era reformasi ini memiliki hubungan genealogis dengan kebijakan politik agama pada zaman pemerintahan kolonialisme Belanda maupun pemerintahan militerisme Jepang. Daniel Dhakidae menyebutkan dua penguasa rezim Orde Lama maupun Orde Baru merupakan penganut setia mazhab Snouck Hurgronje (Hurgonjesian) dalam pengelolaan keragaman agama. Satu sisi pemerintah memberikan dukungan seluas-luasnya kepada agama-agama besar utamanya Islam dalam hal pelaksanaan kegiatan dan seremonial keagamaan, atau dukungan untuk sarana dan prasarana ritual keagamaan, dan pada saat yang sama melakukan represi jika mulai mengarah pada aktivitas politik. ${ }^{6}$ Melalui kebijakan tersebut, hubungan antara Islam dan negara, khususnya yang melibatkan gerakan politik Islam selama dua rezim pemerintahan pasca-kemerdekaan tersebut tidak pernah berhenti, serta mengalami pasang surut yang saling memanfaatkan atau bahkan saling mengintervensi.

Secara umum, setelah menyatakan kemerdekaannya Indonesia setidaknya dihadapkan dengan dua isu penting: Pertama, bagaimana mempertahankan diri dari kemungkinan kembalinya penjajahan Belanda

${ }^{6}$ Daniel Dhakidae, Cendekiawan dan Kekuasaan dalam Negara Orde Baru (Jakarta: PT. Gramedia Pustaka Utama, 2003), 531-532. 
dan sekutunya; Kedua, bagaimana mengamankan Indonesia dari berlarutnya partarungan ideologi antara dua kekuatan politik yang terjadi antara dua kelompok: kelompok nasionalis sekuler dan nasionalis Islam. ${ }^{7}$

Pertarungan ideologi yang utama adalah sekitar pembentukan dasar negara Indonesia. Meskipun proklamasi telah dikumandangkan, Indonesia yang baru merdeka dihadapkan dengan kenyataan bahwa masing-masing merasa tidak puas terhadap rumusan dasarnegara. Kelompok nasionalis Islam yang juga terlibat dalam panitia persiapan kemerdekaan Indonesia menginginkan Islam sebagai dasar negara. Adapun tema yang menjadi perdebatan sengit dan memakan waktu menyangkut dasar negara Pancasila, terutama pada sila Ketuhanan Yang Maha Esa. Di pihak lain, rumusan Piagam Jakarta yang berbunyi "Ketuhanan dengan kewajiban menjalankan syariat bagi pemeluknya" tidak cukup memuaskan kelompok nasionalis nonagama. Atas prakarsa Mohammad Hatta, sila pertama akhirnya disepakati menjadi "Ketuhanan Yang Maha Esa”. Itu terjadi setelah Hatta melakukan lobi dan/atau kompromi dengan beberapa nasionalis Islam, antara lain Tengku Hasan dan $\mathrm{Ki}$ Bagus Hadikusumo menjelang dilaksanakannya rapat 18 Agustus 1945.

Adapun yang menjadi pemikiran adalah adanya pertimbangan mengenai kemungkinan buruk pada awal kemerdekaan jika "tujuh kata" itu tetap dipaksakan tertuang di Pancasila. ${ }^{8}$ Kompromi setengah hati terjadi bukan tanpa alasan. Meskipun sila Ketuhanan Yang Maha Esa sudah ditetapkan sebagai bagian dasar negara, bentuk negara Indonesia tetap menyisakan banyak persoalan. Negara bernama Indonesia yang diproklamasikan pada 17 Agustus 1945 menjadi negara "yang bukan-

${ }^{7}$ Yudi Latif, Negara Paripurna, Historisitas, Rasionalitas dan Aktulitas Pancasila (Jakarta: Gramedia Pustaka Utama, 2011), 69.

${ }^{8}$ Yudi Latif, Negara Paripurna, Historisitas, Rasionalitas dan Aktulitas Pancasila, 83. bukan", dalam pengertian bukan negara agama dan bukan negara sekuler. Dasar negara Indonesia dimaknai sesuai dengan kepentingan masing-masing kelompok. Sebagian kelompok Islam tetap menginginkan Islam sebagai dasar negara, sementara kelompok nasionalis sekuler tetap konsisten menolak agama apa pun sebagai dasar negara.

Perdebatan tentang seputar dasar negara "yang bukan negara agama dan juga bukan negara sekuler" antara kelompok nasionalis Islam yang secara ekplisit disuarakan oleh $\mathrm{Ki}$ Bagoes Hadikoesoemo pada 31 Mei 1945 dan kelompok nasionalis sekuler seperti disampaikan oleh Soepomo dan lain-lain, kemudian direspons oleh M. Hatta. Dalam pidatonya Hatta menjelaskan:

"Kita tidak akan mendirikan negara dengan dasar perpisahan antara "agama" dan "negara", melainkan kita akan mendirikan negara modern di atas dasar perpisahan antara urusan agama dengan urusan negara. Kalau urusan agama juga dipegang oleh negara, maka agama menjadi perkakas negara, dan dengan itu hilang sifatnya yang murni’"? Pidato Hatta tidak sepenuhnya diterima utamanya oleh kelompok nasionalis religius. Pertarungan sengit tersebut secara formal "dimenangkan" oleh kelompok sekuler. Dan kenyataan ini tentu harus diterima oleh kelompok nasionalis Islam. Dalam suasana kebatinan seperti itulah, pemerintahan Orde Lama di bawah kepemimpinan Presiden Soekarno dan Wakil Presiden Muhammad Hatta, enam bulan setelah kemerdekaan mengeluarkan Surat Ketetapan Pemerintah pada tanggal 2 Januari 1946 Nomor 1/SD/1946 tentang pembentukan atau pendirian Kementerian Agama atau yang disebut dengan Departemen Agama. ${ }^{10}$

${ }^{9}$ Yudi Latif, Negara Paripurna, Historisitas, Rasionalitas dan Aktulitas Pancasila, 73.

${ }^{10} \mathrm{~J}$. B. Banawiratma, dkk., Dialog Antarumat Beragama, Gagasan dan Praktek di Indonesia (Bandung: Mizan, 2010, 66. 
Oleh banyak pengamat, pembentukan Kementerian Agama tersebut tidak hanya dilihat sebagai bentuk kompromi, tetapi juga merupakan imbalan atau hadiah pemerintah RI terhadap umat Islam atas kesediaan mereka menghapuskan "tujuh kata" dalam Piagam Jakarta. Setelah terbentuknya Kementerian Agama peta bumi politik agama di Indonesia pada era Orde Lama dan setelahnya sangat tidak bisa dilepaskan dari keberadaan Kementerian Agama (Departemen Agama) tersebut. Kebijakan keagamaan yang dianggap intervensi negara terhadap agama paling tidak menyangkut tiga ranah pokok.

Pertama, intervensi negara terhadap kehidupan beragama dalam bentuk campur tangan negara terhadap keyakinan agama masyarakat, yang sesungguhnya bersifat sangat privat. Negara tidak lagi menjadi pengelola yang berkewajiban memfasilitasi serta mengatur atau menjaga eksistensi masing-masing agama dalam kerangka masyarakat yang majemuk, tetapi justru memasuki ranah yang sesungguhnya menjadi hak masing-masing agama atau yang disebut forum internum agama. Akibatnya, telah terjadi semacam masifikasi agama dalam kepentingan negara yang menyangkut upaya penyeragamaan, sehingga kedaulatan agama terpecah ke dalam dua model pengaturan atas agama, yakni agama dan kepercayaan yang diakui di satu pihak, dan agama dan kepercayaan yang tidak "diakui" di lain pihak.

Mirip seperti pemerintahan kolonial, pemerintah Orde Lama maupun Orde Baru dengan mudah menetapkan suatu aliran dalam agama sebagai aliran sesat atau menyimpang, jika kelompok keagamaan itu melakukan aktivitas politik yang berbeda dengan pandangan keagamaan mainstream. Agamaagama dominan juga memanfaatkan situasi intervensi negara ini untuk mengambil keuntungan berupa perolehan penganut secara kuantitas, dengan menuduh kelompok keyakinan yang berbeda dengan pandangan mainstream sebagai pihak yang akan melakukan perlawanan atau makar terhadap negara. Dengan demikian, isu purifikasi di dalam agama dominan memperoleh keuntungan.

Kedua, pendefinisian agama resmi (official religion) oleh negara yang mengacu pada kepentingan agama "resmi", di mana penetapan sesuatu agama sebagai resmi hanya dengan mengacu pada tradisi "Abrahamic Religions". Termasuk di dalam hal ini negara telah menetapkan pendefinisian agama yang benar atau sehat dan agama yang tidak benar atau yang tidak sehat. Intervensi ini dikukuhkan melalui UU. Nomor: 1/PNPS/1965, yang seakan memberikan mandat penuh kepada Kementerian Agama untuk mengindetifikasi atau mendefinisikan suatu agama yang danggap benar atau salah. ${ }^{12}$ Pendefinisian tunggal terhadap kepercayaan masyarakat yang kemudian disebut sebagai "Agama", menurut Niel Mulder baru berhasil dirumuskan tahun 1961, yang mendasari pijakan UU PNPS tersebut di atas.

Ketiga, konsekuensi dari penetapan agama resmi negara, termasuk mendefinisikan agama yang benar dan yang salah oleh negara, kelompok agama resmi, terutama yang memiliki klaim paling benar, memperoleh manfaat besar dari situasi tersebut. Kelompok agama resmi, yang dalam praktiknya tiada lain adalah "agama yang diakui”, kemudian merasa berkewajiban untuk mendakwahkan agamanya itu. Dalam konteks inilah, kebijakan intervensi terhadap pendefinisian benar atau salahnya suatu agama oleh negara pada dasarnya merupakan desakan sekaligus bentuk intervensi dari kelompok agama dominan terhadap negara. Akibatnya, negara tidak lagi memiliki kepekaan dalam semangat menghargai perbedaan pandangan atau kemajemukan pemikiran dalam agama. Oleh sebab itu, agama dominan seakan

${ }^{11} \mathrm{~J}$. M. Atkinson, "Religion and Dialogue, The Construction of an Indonesian Minority Religion", 77.

${ }^{12}$ Zainal Abidin Bagir, dkk., Pluralisme Kewargaan, Arah Baru Politik Keragaman di Indonesia (Bandung: MizanCRCS, 2011), 117. 
memiliki amunisi baru untuk melakukan penindasan terhadap agama-agama lokal.

Keempat, setelah kelompok keyakinan non-mainstream dianggap menyimpang, negara melalui Kementerian Agama mewacanakan isu "pembinaan" atau "mengembalikan aliran kepercayaan atau agama lokal kepada agama induknya", meskipun agama dominan bukanlah induk dari aliran kepercayaan. Wacana pembinaan tersebut pada dasarnya merupakan "pemaksaan" terhadap keyakinan lain daripada pembinaan itu sendiri. Implikasi dari bentuk intervensi ini, kelompok agama resmi menjadi sewenang-wenang memidanakan siapa saja dari kelompok agama lokal. Dalam hal ini, agama besar juga telah terlibat dalam penghancuran kelompok-kelompok lain yang memiliki tafsir dan/atau pemahaman berbeda.

Senjata paling ampuh yang digunakan terhadap keyakinan lokal adalah isu penodaan agama, atau menyimpang dari pokok-pokok agama. Dengan tuduhan tersebut, agama dan kepercayaan lokal dengan mudah dianggap sebagai sesat, dan sering ditempeli dengan stigma seperti "pengacau keamanan". Tuduhan terhadap agama lokal sebagai kepercayaan menyimpang dan pengacau keamanan menjadi sangat masif pada akhir periode Orde Lama di bawah rezim Soekarno. Di pihak lain, melalui klaim kebenaran dan kewajiban untuk mendakwahkan kebenaran agama, timbul benturan antar-agama yang dianggap resmi oleh negara itu sendiri, karena rebutan lahan dakwah. Islam sebagai mayoritas di Indonesia berebut lahan dakwah dengan Kristen, karena samasama meyakini kewajiban untuk menyebarkan agama.

Fenomena berebut umat atau lahan dakwah tersebut memakan tumbal. Kelompok agama lokal Nusantara menjadi sasaran paling empuk. Penyingkiran, bahkan pemusnahan terhadap pengikut agama lokal Nusantara menjadi semakin sempurna. Secara kronologis, dinamika penindasan terhadap agama lokal dapat dirunut sebagai berikut:
Pertama, setelah kemerdekaan tahun 1945, selain berseberangan dengan kelompok nasionalis sekuler, kelompok Islam juga berhadapan dengan kelompok penganut agama lokal Nusantara, yang saat itu disebut kelompok kebatinan. Dalam pembangunan konstitusi, misalnya, K.H. Wahid Hasyim mengusulkan Pasal 29 Ayat 2 yang berbunyi, "Negara menjamin kemerdekaan tiap-tiap penduduk untuk memeluk agamanya masing-masing dan beribadah menurut agamanya itu". Usulan ayahanda Gus Dur tersebut segera direspons oleh K.R.M.T. Wongsonegoro, dengan menambahkan kalimat, "Dan beribadah menurut agama dan kepercayaannya itu". Lebih tegas Wongsonegoro menyebutkan bahwa yang dimaksud dengan "kepercayaannya itu" secara implisit merujuk kepada eksistensi agama lokal dengan tradisi kebatinannya. ${ }^{13}$ Dalam pandangan K.R.M.T Wongsonegoro, usulan K.H. Wahid Hasyim mengisyararkan bahwa negara boleh memaksa orang-orang Islam untuk menjalankan syariat agamanya.

Kedua, setelah Presiden Soekarno meresmikan Kementerian Agama melalui Keppres tertanggal 2 Januari 1946, fokus umat Islam adalah melakukan pembenahan internal, termasuk secara tidak langsung melakukan Islamisasi kepada masyarakat Indonesia, terutama terhadap kelompok-kelompok yang dianggap belum beragama, yaitu penganut agama lokal Nusantara. Apalagi, setelah September 1948, ketika untuk pertama kalinya terjadi ketegangan dalam bentuk konflik fisik antara kelompok PKI dan kelompok kiai di Jawa, yang memuncak di Madiun. PKI mendapat dukungan dari kelompok "penghayat" karena konsep agrarianya. Karena itu, kelompok yang oleh Geertz disebut "Abangan" itu menjadi semakin terpojok atas peristiwa tersebut. ${ }^{14}$

${ }^{13}$ T. S. Sutanto, Merayakan Kebebasan, 125.

${ }^{14}$ Clifford Geertz, The Religion of Java (Chicago and London: The University of Chicago Press, 1960), 1. 


\section{RAGAM REGULASI DISKRIMINATIF}

Diskriminasi terhadap kelompok agama non mainstream khususnya terhadap agama lokal nusantara ditengarai terjadi secara struktural sistematis dan massif karena melibatkan negara dengan produk-produk regulasinya. Tentang bagaimana bentuk kebijakan diskriminatif berbasis kebijakan. Regulasi diskriminatif dikutip ulang secara penuh dari penelitian penulis yang termuat dalam buku Religionisasi Indonesia dan Laporan Kebebasan Beragama di Indonesia tentang kondisi pemenuhan hak konstitusioanl Penghayat Kepercayaan Terhadap Tuhan Yang Maha Esa. ${ }^{15}$

\begin{tabular}{|c|c|c|c|}
\hline No & $\begin{array}{c}\text { Poin } \\
\text { Diskrimin } \\
\text { asi }\end{array}$ & $\begin{array}{c}\text { Regulasi Yang } \\
\text { Digunakan }\end{array}$ & Dampak \\
\hline 1 & $\begin{array}{l}\text { Penolakan } \\
\text { pengakuan } \\
\text { identitas } \\
\text { sebagai } \\
\text { penghayat } \\
\text { atau } \\
\text { penganut } \\
\text { agama lokal }\end{array}$ & $\begin{array}{l}\text { - } \text { Paradigma UU } \\
\text { No. } \\
\text { 1/PNPS/1965 } \\
\text { TAP MPR } \\
\text { No.IV/MPR/ } \\
1978 \\
\text { melandasi } \\
\text { seluruh } \\
\text { kebijakan } \\
\text { yangdiambil } \\
\text { negara } \\
\text { terhadap } \\
\text { penghayat. } \\
\text { Surat Edaran } \\
\text { Mendagri No: } \\
\text { 477/74054 } \\
\text { tanggal 18 } \\
\text { November } \\
\text { 1978 } \\
\text { Instruksi } \\
\text { Menteri } \\
\text { Agama RI No: } \\
\text { 14tahun 1978 } \\
\text { tentang } \\
\text { Tindak Lanjut } \\
\text { Instruksi } \\
\text { Menteri } \\
\text { AgamaNo: } 4 \\
\end{array}$ & $\begin{array}{l}\text { Eksistensi agama } \\
\text { lokal sejak } \\
\text { keluarnya surat } \\
\text { edarat dua } \\
\text { menteri tersebut } \\
\text { yang } \\
\text { menggunakan } \\
\text { logika UU PNPS } \\
\text { selalu } \\
\text { dipermasalahkan } \\
\text { bahkan } \\
\text { didiskriminasi } \\
\text { sejak lahir } \\
\text { sampai mati }\end{array}$ \\
\hline
\end{tabular}

${ }^{15}$ Tabel tentang regulasi diskriminatif merupakan olahan dari berbagai sumber yang penulis lakukan dan telah dimuat dalam Sudarto, Religionisasi Indonesia; Sejarah Perjumpaan Agama Lokal dan Agama Pendatang (Jakarta: PT. Gramedia Pustaka Utama, 2016) dan Sudarto, Kondisi Pemenuban Hak Konstitusional Penghayat Kepercayaan Terbadap Tuban Yang Maha Esa (Jakarta: Setara Institute, 2017).

\begin{tabular}{|c|c|c|c|}
\hline & & $\begin{array}{l}\text { tahun } 1978 \\
\text { tentang } \\
\text { Kebijaksanaan } \\
\text { mengenai } \\
\text { Aliran-aliran } \\
\text { Kepercayaan }\end{array}$ & \\
\hline 2 & $\begin{array}{l}\text { Kasus } \\
\text { hilangnya } \\
\text { hak } \\
\text { mendapatk } \\
\text { an status } \\
\text { sebagai } \\
\text { TNI atau } \\
\text { Polri }\end{array}$ & $\begin{array}{l}\text { UU-28/1997 } \\
\text { tentang Kepolisian } \\
\text { Negara RI. } \\
\text { Undang-undang } \\
\text { ini sudah tidak } \\
\text { berlaku dengan } \\
\text { lahirnya UU } \\
\text { Kepolisian yang } \\
\text { baru. Pasal } \\
\text { rawannya adalah: } \\
\text { "Pasal } 15 \text { ayat (1) } \\
\text { butir h, yang } \\
\text { tendensius dengan } \\
\text { kecurigaan seolah- } \\
\text { olah aliran } \\
\text { kepercayaan dapat } \\
\text { menimbulkan } \\
\text { perpecahan dan } \\
\text { mengancam } \\
\text { persatuan dan } \\
\text { kesatuan bangsa". }\end{array}$ & $\begin{array}{l}\text { Meskipun UU ini } \\
\text { sudah diganti } \\
\text { namun hak dan } \\
\text { kewajiban ikut } \\
\text { berpartisipasi } \\
\text { untuk bela } \\
\text { negara dengan } \\
\text { menjadi TNI } \\
\text { atau Polisi } \\
\text { dihalangi }\end{array}$ \\
\hline 3 & $\begin{array}{l}\text { Menyangku } \\
\mathrm{t} \\
\text { pencatatan } \\
\text { perka- } \\
\text { winan bagi } \\
\text { peng-hayat } \\
\text { di Kantor } \\
\text { Catatan } \\
\text { Sipil dan } \\
\text { "tatacara } \\
\text { sumpah } \\
\text { perkawinan } \\
\text { dan } \\
\text { sebagainya } \\
\text { hanya ada } \\
\text { menurut } \\
\text { agama } \\
\text { sesuai } \\
\text { dengan } \\
\text { peraturan } \\
\text { perundang- } \\
\text { undangan } \\
\text { yang } \\
\text { berlaku." }\end{array}$ & $\begin{array}{l}\text { UU No. } 1 \text { tahun } \\
1974 \text { tentang Per- } \\
\text { kawinan. } \\
\text { Dikuatkan dengan: } \\
\text { - Surat Edaran } \\
\text { MenteriDalam } \\
\text { Negeri } \\
\text { No.477/74054 } \\
\text { tanggal } \\
\text { 18November } \\
\text { 1978 } \\
\text { perihalpe- } \\
\text { tunjuk } \\
\text { pengisiankolo } \\
\text { m "aga-ma" } \\
\text { padalampiran } \\
\text { SK Men- } \\
\text { dagriNo: } \\
\text { 221a/1975 } \\
\text { tentangPencat } \\
\text { atan } \\
\text { Perkawinan } \\
\text { dan Perceraian } \\
\text { pada Kantor } \\
\text { Catatan Sipil } \\
\text { Surat Edaran } \\
\text { dari Menteri } \\
\text { Agama kepada } \\
\text { Gubernur/K } \\
\text { DHTingkat I } \\
\text { Jatim No: } \\
\text { B/5943/78 } \\
\text { tanggal3 Juli } \\
\text { 1978 tentang }\end{array}$ & $\begin{array}{l}\text { - Perkawinan } \\
\text { pasangan } \\
\text { kelompok } \\
\text { penghayat } \\
\text { tidak bisa } \\
\text { dicatatkan. } \\
\text { Sebab } \\
\text { menurut } \\
\text { ketentuan } \\
\text { surat ini, } \\
\text { "dalam } \\
\text { Negara } \\
\text { Republik } \\
\text { Indonesia } \\
\text { yang } \\
\text { berdasarkan } \\
\text { Pancasila } \\
\text { tidak dikenal } \\
\text { adanya } \\
\text { tatacara } \\
\text { sumpah } \\
\text { perkawinan } \\
\text { aliran } \\
\text { kepercayaan. } \\
\text { Suratkawin } \\
\text { yang } \\
\text { dikeluar-kan } \\
\text { Yayasan } \\
\text { Pusat Srati } \\
\text { Dharma, } \\
\text { Yogyakarta } \\
\text { menjadi } \\
\text { masalah } \\
\text { besar bagi } \\
\end{array}$ \\
\hline
\end{tabular}




\begin{tabular}{|c|c|c|c|}
\hline & & $\begin{array}{l}\text { Masalah Aliran } \\
\text { Kepercayaan } \\
\text { - Surat Dirjed } \\
\text { PUOD } \\
\text { Nomor : } \\
474.2 / 3069 / P \\
\text { UOD tanggal } \\
19 \text { Oktober } \\
1995\end{array}$ & $\begin{array}{l}\text { para } \\
\text { penghayat. }\end{array}$ \\
\hline 4 & $\begin{array}{l}\text { Penolakan } \\
\text { pencatatan } \\
\text { akte } \\
\text { kelahiran } \\
\text { anak bagi } \\
\text { pasangan } \\
\text { penghayat }\end{array}$ & $\begin{array}{l}\text { Surat edaran } \\
\text { Menko Kesra No: } \\
\text { B.336/ MENKO/ } \\
\text { KESRA/VII/198 } \\
\text { tanggal 16 Juli } \\
1980 \text { perihal } \\
\text { Penyempurnaan } \\
\text { formulir Sensus } \\
\text { penduduk. } \\
\text { Diperkuat dengan } \\
\text { Radiogram Depag } \\
\text { No: MA/610 } \\
\text { /1980 kepada } \\
\text { seluruh Kepala } \\
\text { Kanwil Depag di } \\
\text { seluruh Indonesia } \\
\text { tanggal 22 } \\
\text { September } 1980 .\end{array}$ & $\begin{array}{l}\text { Anak-anak } \\
\text { keluarga } \\
\text { pengha-yat } \\
\text { selain tidak } \\
\text { bisa menda- } \\
\text { patkan hak } \\
\text { pendidikan } \\
\text { sesuai } \\
\text { dengan } \\
\text { agama dan } \\
\text { keyakinanny } \\
\text { a namun } \\
\text { juga dipaksa } \\
\text { mengikuti } \\
\text { pelajaran } \\
\text { agama } \\
\text { dominan. } \\
\text { Pada bagian } \\
\text { lain mereka } \\
\text { juga } \\
\text { mendapat } \\
\text { stigma } \\
\text { sebagai } \\
\text { orang tidak } \\
\text { beragama } \\
\text { anak PKI, } \\
\text { atheis dan } \\
\text { lain-lain. } \\
\text { Di beberapa } \\
\text { daerah } \\
\text { pasangan } \\
\text { keluarga } \\
\text { yang } \\
\text { menikah } \\
\text { dalam agama } \\
\text { lokal harus } \\
\text { membuat } \\
\text { surat } \\
\text { pernyataan } \\
\text { anak diluar } \\
\text { nikah. }\end{array}$ \\
\hline 5 & $\begin{array}{l}\text { Penolakan } \\
\text { dan } \\
\text { hambatan } \\
\text { dalam } \\
\text { urusan } \\
\text { pemakama } \\
\text { n bagi } \\
\text { warga } \\
\text { penghayat }\end{array}$ & $\begin{array}{l}\text { Surat Menteri } \\
\text { Agama kepada } \\
\text { para Gubernur/ } \\
\text { KDH Tingkat I } \\
\text { seluruh Indonesia } \\
\text { No: } \\
\text { B.VI/11215/1978 } \\
\text { tanggal 18 } \\
\text { Oktober 1978 } \\
\text { perihal Masalah } \\
\text { Penyebutan }\end{array}$ & $\begin{array}{l}\text { Banyak kasus } \\
\text { jenazah warga } \\
\text { penghayat tidak } \\
\text { bisa dikuburkan } \\
\text { di pemakaman } \\
\text { umum karena } \\
\text { menurut } \\
\text { ketentuan surat } \\
\text { ini, "Dalam } \\
\text { Negara Republik } \\
\text { Indonesia yang }\end{array}$ \\
\hline
\end{tabular}

\begin{tabular}{|c|c|c|c|}
\hline & & $\begin{array}{l}\text { Agama, } \\
\text { Perkawinan, } \\
\text { Sumpah jabatan } \\
\text { dan Penguburan } \\
\text { Jenazah bagi Umat } \\
\text { Beragama yang } \\
\text { dihubungkan } \\
\text { dengan Aliran } \\
\text { Kepercayaan }\end{array}$ & $\begin{array}{l}\text { berdasarkan } \\
\text { Pancasila tidak } \\
\text { dikenal adanya } \\
\text { penguburan } \\
\text { menurut Aliran } \\
\text { Kepercayaan, } \\
\text { dan tidak dikenal } \\
\text { pula penyebutan } \\
\text { Aliran } \\
\text { Kepercayaan' } \\
\text { sebagai 'Agama' } \\
\text { baik dalam Kartu } \\
\text { Tanda Penduduk } \\
\text { (KTP) dan lain- } \\
\text { lain. }\end{array}$ \\
\hline 6 & $\begin{array}{l}\text { Penolakan } \\
\text { pendirian } \\
\text { tempat } \\
\text { peribadatan } \\
\text { atau } \\
\text { persujudan } \\
\text { bagi warga } \\
\text { penghayat }\end{array}$ & $\begin{array}{l}\text { SKB Menteri } \\
\text { Agama dan } \\
\text { Menteri Dalam } \\
\text { Negeri membuat } \\
\text { Keputusan } \\
\text { Bersama No. } \\
01 / \text { ber- } \\
\text { Mdn/1969, } 13 \\
\text { September 1969, } \\
\text { yang mengatur } \\
\text { pendirian tempat } \\
\text { ibadah. SKB ini } \\
\text { kemudian } \\
\text { diperbaharui pada } \\
\text { era Reformasi } \\
\text { dengan munculnya } \\
\text { PBM No.8 dan } 9 \\
\text { tahun } 2006 \\
\text { tentang pendirian } \\
\text { rumah ibadah dan } \\
\text { FKUB }\end{array}$ & $\begin{array}{l}\text { Selain kelompok } \\
\text { agama-agama } \\
\text { "minoritas" yang } \\
\text { kesulitan } \\
\text { mendirikan } \\
\text { rumah ibadah, } \\
\text { kelompok agama } \\
\text { lokal juga sulit } \\
\text { mendirikan } \\
\text { tempat } \\
\text { persujudan. }\end{array}$ \\
\hline 7 & $\begin{array}{l}\text { Pengisian } \\
\text { kolom } \\
\text { agama } \\
\text { sesuai } \\
\text { dengan } \\
\text { agama dan } \\
\text { kepercayaa } \\
\text { n-nya pada } \\
\text { KTP }\end{array}$ & $\begin{array}{l}\text { Pada } 1975 \\
\text { pada sidang } \\
\text { Kesra terkait } \\
\text { dengan } \\
\text { pengisian } \\
\text { kolom agama } \\
\text { di KTP ada } \\
\text { administrasi } \\
\text { kependudukan } \\
\text { lainnya, } \\
\text { dibolehkan } \\
\text { mengisi } \\
\text { agama/Keperc } \\
\text { ayaan } \\
\text { Surat } \\
\text { Keputusan } \\
\text { Menko Kesra } \\
\text { No: } \\
\text { B.310/MENK } \\
\text { O/KESRA/ } \\
\text { VI/1980 } \\
\text { tanggal 30 Juni } \\
\text { 1980 dan Surat } \\
\text { Menteri } \\
\text { Agama kepada }\end{array}$ & $\begin{array}{l}\text { Kelompok } \\
\text { Agama Lokal } \\
\text { tidak bisa } \\
\text { mengisi kolom } \\
\text { agama sesuai } \\
\text { dengan agama } \\
\text { dan } \\
\text { kepercayaannya. } \\
\text { Prihal pengisian } \\
\text { kolom agama } \\
\text { beberapa kali } \\
\text { mengalami } \\
\text { perubahan, } \\
\text { semula dilarang } \\
\text { sama sekali, } \\
\text { kemudian boleh } \\
\text { dikosongkan } \\
\text { atau ditulis tanda } \\
\text { strip (-) }\end{array}$ \\
\hline
\end{tabular}




\begin{tabular}{|c|c|c|c|}
\hline & & $\begin{array}{l}\text { Menteri Dalam } \\
\text { Negeri No: } \\
\text { B.VI/5996/19 } \\
80 \text { tanggal } 7 \\
\text { Juli } 1980 \\
\text { perihal } \\
\text { Perkawinan, } \\
\text { Kartu } \\
\text { Penduduk dan } \\
\text { Kematian para } \\
\text { Penghayat } \\
\text { Kepercayaan } \\
\text { Tuhan Yang } \\
\text { Maha Esa }\end{array}$ & \\
\hline 8 & $\begin{array}{l}\text { Kebebasan } \\
\text { berekspresi } \\
\text { dan } \\
\text { pengemban } \\
\text { gan diri } \\
\text { bagi } \\
\text { komunitas } \\
\text { penghayat }\end{array}$ & $\begin{array}{l}\text { Keputusan Jaksa } \\
\text { Agung } \\
\text { RI No. KEP, 108/ } \\
\text { J.A./5/1984 } \\
\text { tentang } \\
\text { pembentukan Tim } \\
\text { Koordinasi } \\
\text { Pengawasan } \\
\text { Aliran } \\
\text { Kepercayaan } \\
\text { Masyarakat. } \\
\text { Diperbaharui } \\
\text { dengan Surat } \\
\text { Keputusan Jaksa } \\
\text { Agung RI No: } \\
\text { Kep. 004/ J.A./ } \\
\text { 01/1994 tentang } \\
\text { Pembentukan Tim } \\
\text { Koordinasi } \\
\text { Pengawasan } \\
\text { Aliran } \\
\text { Kepercayaan } \\
\text { Masyarakat } \\
\text { (PAKEM) }\end{array}$ & $\begin{array}{l}\text { Komunitas } \\
\text { Agama Lokal } \\
\text { sengaja } \\
\text { dikerdilkan atau } \\
\text { bahkan dibasmi, } \\
\text { dalam hal ini } \\
\text { Tim PAKEM } \\
\text { bertugas meneliti } \\
\text { dan menilai } \\
\text { secara cermat } \\
\text { perkembangan } \\
\text { suatu Aliran } \\
\text { Kepercayaan } \\
\text { untuk } \\
\text { mengetahui } \\
\text { dampaknya bagi } \\
\text { Ketertiban dan } \\
\text { Ketentraman } \\
\text { Umum", serta } \\
\text { "dapat } \\
\text { mengambil } \\
\text { langkah, langkah } \\
\text { aktif dan } \\
\text { preventif sesuai } \\
\text { dengan } \\
\text { ketentuan } \\
\text { perundangundan } \\
\text { gan yang } \\
\text { berlaku" (pasal 3, } \\
\text { butir b dan d) }\end{array}$ \\
\hline 9 & $\begin{array}{l}\text { Pemaksaan } \\
\text { berorganisa } \\
\text { si untuk } \\
\text { bisa } \\
\text { melangsun } \\
\text { gkan atau } \\
\text { mendapatk } \\
\text { an akte } \\
\text { perkawinan } \\
\text { bagi } \\
\text { kelompok } \\
\text { penghayat }\end{array}$ & $\begin{array}{l}\text { PP } 81 \text { No } 37 / 2007 \\
\text { tentang Peraturan } \\
\text { pelaksanaan UU } \\
\text { No. 23/2006 } \\
\text { tentang } \\
\text { Administrasi } \\
\text { kependudukan }\end{array}$ & $\begin{array}{l}\text { Komunitas yang } \\
\text { tidak } \\
\text { berorganisasi } \\
\text { dan tidak } \\
\text { memiliki pemuka } \\
\text { penghayat, tidak } \\
\text { dapat } \\
\text { memperoleh } \\
\text { akte-perkawinan } \\
\text { atau akan } \\
\text { dipersulit. }\end{array}$ \\
\hline
\end{tabular}

\section{TAWARAN PENGELOLAAN KEBERAGAMAN}

Di tengah era transisi demokrasi saat ini, Indonesia sedang menghadapi dihadapkan dengan dua momen kritis (critical juncture). Pada satu sisi demokrasi menyediakan ruang pertarungan bebas setiap kekuatan politik mengekpresikan pandangan dan sikap politiknya. Namun pada saat yang sama, bangsa Indonesia juga berada dalam ancaman anarki demokrasi, disebabkan rasa frustasi terhadap berlikunya jalan demokrasi. Antara lain munculnya kelompok anti demokrasi yang ingin mengambil alih kekuasaan prosedur di luar demokrasi. ${ }^{16}$

Dalam konteks demokratisasi di Indonesia, meskipun bukan faktor utama, agama-agama terutama Islam selalu memainkan peran besar dalam setiap tahapan transisi tersebut. Robert W. Hefner menyebutkan, Indonesia sejak berdirinya tahun 1945, telah mengalami pertarungan sengit antara kelompok nasionalis non-agamis yang berkeinginan mengakomodasi banyak agama ("multiconfessional'), dengan kelompok-kelompok Muslim yang menginginkan agamanya menjadi "perkakas" negara untuk mewujudkan impian, guna menperteguh kesalehan Islami, bagi sebagian masyarakat yang mengidentifikasi diri sebagai Muslim. ${ }^{17}$

Sementara itu, dalam perspektif demokrasi, keberagaman ekspresi, termasuk dari kelompok Islam merupakan sesuatu yang dijamin keabsahannya. Persoalannya bagaimana keberagaman ekspresi tersebut dijalankan dengan cara yang lebih rasional dan beradab? Prinsip pokok yang harus dikembangkan dalam negara majamuk adalah melindungi dan mengakomodasi hak-hak kelompok minoritas

${ }^{16}$ Alfred Stepan, Religion, Democracy, and the Twin Toleration (Project Muse: John Hopkins University Press, 2000), 297.

${ }^{17}$ Robert W. Hefner, dkk. Remaking Muslim Politics: Pluralism, Contestation, Democratization (Princeton: Princeton University Press, 2005), 25. 
dalam konstitusi yang demokratis. ${ }^{18}$ Minoritas dalam pengertian di sini bisa disebabkan karena faktor agama, kelompok keyakinan, etnis, jenis kelamin termasuk perbedaan orientasi seksual dan sebagainya. Oleh sebab itu agar kelompokkelompok minoritas dapat terlindungi dan terakomodasi kepentingannya, kelompok dominan tidak dapat memaksakan kehendaknya menuntut perlakuan istimewa dari negara, atau yang oleh Stepan disebut "privileged prerogatives". 19

Oleh karena itu di dalam demokrasi, pemerintah yang terpilih secara demokratis harus memerintah secara konstitusional sehingga tidak ada kelompok-kelompok yang terdominasi atau tersingkir atas desakan kelompok dominan manapun. ${ }^{20}$ Tegasnya, dalam demokrasi setiap warga negara dengan berbagai latar belakangnya, memiliki hak yang setara (equal) untuk berpendapat termasuk terlibat merencanakan kebijakan publik yang akanmempengaruhi kehidupan mereka. Termasuk dalam konteks ini, kelompokkelompok yang berbeda dapat diperlakukan secara berbeda karena perbedaan identitasnya. ${ }^{21}$ Institusi-institusi, baik pemerintah maupun non-pemerintah, seperti agama seharusnya tidak memiliki keistimewaan dalam konstitusi untuk mendikte dan/atau memveto keputusan yang telah dibuat oleh pemerintah yang dipemilih secara demokratis. ${ }^{22}$

Dalam konteks inilah untuk merawat kemurnian demokrasi, negara harus membangun jarak bermartabat terhadap agamaagama. Jarak bermartabat ini oleh Abdullah Ahmed An-Na'im disebut sebagai “the neutrality

\footnotetext{
${ }^{18}$ Ayelet Shachar, "Multicultural Jurisdiction", Law Review, Vol. 35, No. 2 (Summer, 2000): 12.

${ }^{19}$ Alfred Stepan, Religion, Democracy, and the Twin Toleration, 116.

${ }^{20}$ A.A. An Na'im, Islam dan Negara Sekular Negosiasi Masa Depan Syari'ah (Bandung: Mizan, 2010), 22. 61.

${ }^{21}$ Zainal Abidin Bagir, dkk., Pluralisme Kewargaan,

${ }^{22}$ Alfred Stepan, Problem of Democratic Transition and Consolidation, Sothern Europe, South America, and Post Comunist Europe (London: John Hopkin University Press, 1996), 116.
}

religion of the state". ${ }^{23}$ Pentingnya menjaga jarak antara agama-negara, bukan dimaksudkan untuk meminggirkan agama-agama dalam ruang privat atau melakukan pemisahan antara agama dan negara secara ketat seperti dalam pengertian "sekulerisme klasik". Namun semata-mata untuk membangun jarak yang berprinsip atau "principled distance". ${ }^{24}$ Dengan membangun jarak berprinsip, antara negara dan agama tidak akan saling mengintervensi sekaligus tidak akan mendiskriminasi disebabkan keberpihan terhadap satu agama atau golongan. Jarak berprinsip atau principle distanced oleh Rajeev Bhargava dimaknai sebagai jarak yang bermartabat, dimana antara agama dan negara saling memiliki posisi tawar dalam mekanisme check and balance. ${ }^{25}$

Pertanyaanya adalah, mengapa antara agama dan negara harus membangun jarak berprinsip? Setidaknya ada dua alasan penting. Pertama, mendiskusikan demokrasi tidak harus sekularisme dalam pengertian memisahkan antara agama dengan negara. Sekularisme bukanlah hal yang intrinsik dalam demokrasi. Yang intrinsik justru negara-agama harus membangun "twin toleration" atau toleransi kembar. ${ }^{26}$ Gagasan dasar dari twin toleration didefinisikan oleh Stepan sebagai batas-batas minimal dan kebebasan bertindak bagi organisasi-organisasi keagamaan. ${ }^{27}$ Kedua, bahwa penyapihan agama-negara secara ketat selain tidak diperlukan juga pada dasarnya akan ditolak oleh agama apapun, terutama bagi negara-negara mayoritas Islam. ${ }^{28}$

\footnotetext{
${ }^{23}$ An Na'im, Islam dan Negara Sekular, 1.

${ }^{24}$ Rajeev Bhargava, Political Theory in Introduction (Perison: Oxford Universty, 2014), 1.

${ }^{25}$ Bhargava, Political Theory in Introduction 1; An Na'im, Islam dan Negara Sekular, 1.

${ }^{26}$ Stepan, Religion, Democracy, and the Twin Toleration, 37.

${ }^{27}$ Stepan, Religion, Democracy, and the Twin Toleration, 37.

${ }^{28}$ A.A. An Na'im, Dekonstruksi Syari'ah, Wacana kebebasan Sipil, Hak Asasi Manusia dan Hubungan internasioan dalam Islam (Jogjakarta: LKiS, 1990), 24.
} 
Kegagalan negara-agama membangun jarak, menyebabkan hubungan antara keduanya menjadi tumpang tindih dan menyebabkan Indonesia menjadi negara yang bukan-bukan. Fenomena itulah yang saat ini dihidupi dalam konteks keberagamaan di Indoesia. Beberapa isu yang sangat tumpang tindih antara lain menyangkut hak pendidikan. Hanya di Indonesia mengurusi hak pendidikan warna negara dikelola oleh dua kementerian. Selain isu pendidikan yang berakibat pemborosan adalah menyangkut pencatatan perkawinan, yang juga melibatkan dua kementerian. Dan yang paling sulit dicerna secara rasional adalah masalah pengelolaan keberagamaan dan keyakinan masyarakat juga harus dikelola oleh dua kementerian. $^{29}$

Oleh karena itu, demi keperluan pengelolaan keberagaman dalam prinsip-prinsip kesetaraan dan keadilan bagi setiap warga negara, mestinya segera dilakukan restrukturisasi pada beberapa Kementerian agama:

Pertama. jika negara menganggap Kementerian Agama masih dibutuhkan, diperlukan restrukturisasi tugas pokok dan fungsi (Tupoksi) Kementerian Agama. Jika selama ini masalah agama dan keyakinan dipisahkan pada dua kementerian. Dalam hal ini Kementerian Agama dan kementerian Pendidikan dan Kebudayaan. Kedepan masalah agama dan kepercayaan (belief) masyarakat harus menjadi kewenangan Kementerian Agama yang sifatnya hanya memfasilitasi.

Tugas Kemeneterian Agama kedepan tidak hanya mengurusi enam agama mainstream (Islam, Protestan, Katolik, Hindu, Budha, dan Konghucu) tapi juga mengurusi agama-agama dan kepercayaan yang secara konstitusional dijamin oleh negara. Untuk kasus agama lokal, yang berdasarkan amar putusan MK 7 November 2017 harus direspon dengan pengelolaan satu atap antara agama-agama dan

${ }^{29}$ Sudarto, Religionisasi Indonesia, 141. kepercayaan (agama lokal) Nusantara. Inilah konsekuensi dari amar putusan menyebut agama tanpa menyebut kepercayaan sebagai bagian pelanggaran konstitusi. ${ }^{30}$ Dengan logika dan amar putusan MK tersebut di atas, maka keberadaan Bakorpakem tidak lagi relevan.

Selain tugas pengelolaan agama-agama dan kepercayaan, Kementerian Agama juga memiliki kewenangan mengurus ziarah suci keagamaan. Antara lain Haji/Umrah, Pilgrimage dan lainnya. Urusan ini mengandaikan bahwa negara akan memfasilitasi semua ziarah suci yang tidak hanya fokus ke Makkah, tetapi juga mungkin ke Yarussalem, Sungai Gangga, atau petilasan-petilasan yang dikonstruksi sebagai suci oleh umat beragama atau kepercayaan yang ada di Indonesia.

Kedua, masalah pendidikan sepenuhnya menjadi kewenangan Kementerian Pendidikan. Jikapun ada kebutuhan pendidikan agama dan keberagamaan masyarakat, mestinya selain menjadi tanggung jawab lembaga keagamaan masing-masing. Kementerian Agama hanya menjadi tempat konsultasi seputar materi pelajaran agama tentang apa yang mesti diajarkan kepada peserta didik.

Ketiga, menyangkut masalah pencatatan pernikahan, tugas negara melalui pencatatan sipil kewarganegaraan mestinya menjadi tugas pokok dan fungsi Kementerian Dalam Negeri melalui Dinas Kependudukan dan Catatan Sipil. Dengan kata lain, terkait masalah pernikahan/perkawinan yang dianggap sakral itu harus menjadi kewenangan agama masingmasing, sementara tugas negara hanyalah mencatatkan warga negara yang hendak, atau sudah menikah dan yang belum menikah. ${ }^{31}$

Gagasan restrukturisasi Kementerian Agama didorong oleh pemahaman bahwa tugas negara dalam masyarakat majemuk adalah menghidupi pluralisme kewargaan. Negara tidak lebih sebagai penanggungjawab dan penjaga

${ }^{30}$ Sudarto, Kondisi Pemenuhan Hak Konstitusional Penghayat Kepercayaan Terhadap Tuhan Yang Maha Esa, 6-7. ${ }^{31}$ Sudarto, Religionisasi Indonesia, 141. 
ruang publik tempat dimana setiap masyarakat dapat partisipasi dalam merespon persoalanpersoalan bersama. Penjagaan ruang publik berarti menjaga ruang tersebut bebas dari dominasi kelompok tertentu dan sekaligus memfasilitasi akses partisipasi semua kelompok masyarakat dengan segala komponen kemajemukannya dalam menjaga kualitas ruang publik tersebut. $^{32}$

Sebagaimana diketahui bersama, dalam negara yang demokratis yang dibutuhkan bukan hanya adanya keberagaman, melainkan bagaimana itu mampu menggumuli (engagement) keragaman itu dengan cara pluralis dan sivik. Dalam kaitan ini ide "civic pluralism" bertemu dengan "civil society". Dalam kaitan ini Robert Hefner menegaskan bahwa masyarakat disebut civic pluralist, ketika anggota-anggotanya membuang niat atau upaya menekan atau mengurangi keragaman dan menjawab segala tantangan-tantangan dengan cara yang lebih damai dan partisipatoris. $^{33}$ Dan pluralisme kewargaan akan tercapai manakala ketika pengelompokan pluralitas tumbuh menjadi pengakuan (recognisi), yang memungkinkan setiap warga negara dapat berpartisipasi membangun institusi publik untuk pengaturan masyarakat secara damai atas dasar pengakuan keragaman dan dialog (engagement) antarkelompok masyarakat.

Paradigma pengelolaan keberagaman sebagaimana terurai di atas, secara eksplisit memberikan pesan kepada kita bahwa negara harus secara sadar memperlakukan kelompok agama lokal nusantara, sebagai bagian local wisdom secara adil dan setara. Apalagi Indonesia merupakan negara yang secara aktif terlibat merativikasi kovenan sipol yang kemudian menjadi undang-undang negara yang tercatat pada UU. No. 12/2005 tentang Rativikasi Kovenan Sipol, dimana dalam Kovenan

${ }^{32}$ Bagir, dkk., Pluralisme Kewargaan, 610.

${ }^{33}$ Robert W. Hefner, Civic Pluralisme Denied? The New Media and Jihadi Violance in Indonesia (Indiana: Indiana University Press, 2003), 163. dimaksud antara agama dan kepercayaan sebagai hak yang setara dan negara harus menghormati, melindungi, dan memenuhi eksistensinya.

Tawaran restrukturisasi pada beberapa kementerian yang salam ini terlibat mengurus masalah agama, akan berdampak positif bagi pembangunan kemajemukan bangsa yang beradab. Antara lain: Pertama, pengelolaan agama akan menjadi lebih efektif, disebabkan hanya ada satu pintu pengelolaan. Hal ini juga akan berdampak pada penghematan anggaran belanja negara untuk kelembagaan yang tidak produktif. Kedua, negara secara tidak langsung telah menempatkan agama dan kepercayaan secara setara dan adil. Tidak ada agama/keyakinan yang diberikan hak previlege dan tidak ada agama yang menjadi anak tiri negara.

\section{KESIMPULAN}

Diskriminasi berbasis agama dan kepercayaan di Indonesia melibatkan empat aktor utama, yakni: Pertama, negara melalui regulasi pengelolaan keberagaman agama, definisi agama, pengawasan dalam perspektif mencurigai (watchdog). Kedua, kelompok agama dominan dengan monopoli terhadap seuatu agama yang dianggap paling benar dan agama tidak benar, agama yang sehat dan tidak sehar. Ketiga, kalangan akademik dengan mindset atropologis berdasarkan kategori-kategoris stigmatif. Keempat, media dengan tayangan yang selain menyudutkan kelompok agama lokal nusantara juga tidak berimbang dalam pemberitaannya. Akibat pengelolaan negara yang tidak cukup berpihak terhadak agama lokal nusantara khususnya, menyebabkan mereka "hopeless" sekaligus bersikap pragmatis demi mempertahankan esensi keyakinan walau tanpa hak untuk mengaktualkan identitas keagamaannya. Lebih jauh konflik kepentingan pada internal agama lokal, menjadi jalan mulus bagi negara cq. pemerintah untuk menundanunda pemenuhan hak penganut agama lokal 
dengan dalih komunitas agama-agama lokal sendiri tidak solid.

Oleh karena itu diperlukan trobosan lebih progresif dan melakukan defnisi ulang terhadap keyakinan yang dikategorikan sebagai agama. Definisi terhadap agama tidak lagi masuk pada forum internum, melainkan sematamata untuk tujuan pengelolaan keberagaman, khususnya agama dalam prinsip-prinsip kewarganegaraan yang setara dan berkeadilan. Tawaran itu antara lain dapat dilakukan melalui restrukturisasi Kementerian Agama dan lembaga-lembaga yang selama ini ikut terlibat mengurusi agama-agama. Hal ini dirasa mendesak antara lain untuk tujuan penyederhanaan birokrasi dan prosedur keagamaan juga penghematan atas anggaran kehidupan beragama. Hal lainnya adalah berangkat dari pemahaman bahwa prinsip dasar dari kewarganegaraan majemuk harus berangkat dari pemikiran setiap komponen kemajemukan diperlakukan setera termasuk dapat diperlakukan berbeda karena perbedaan identitas dalam nuansa affirmative action. Targetnya tidak lain agar setiap komponen kemajemukan tersebut dapat terlibat dan berpartisipasi dalam pemajuan negara bangsa untuk kebaikan masa depan bersama.

Isu pokok dalam demokrasi yang mejemuk itu adalah kemampuan negara mengelola keberagaman doktrin yang komprehensif. ${ }^{34}$ Dengan demikian dalam demokrasi yang konstitusional, mestinya negara harus netral terhadap agama-agama, dalam pengertian tidak menjadikan satu agama sebagai obyek favoritisme. Untuk sampai pada tahap yang demikian langkah jangka pendek yang harus dilakukan adalah membangun budaya literasi dan menciptakan ruang-ruang publik yang netral pula.

Last but not lease, esensi demokrasi adalah kemampuan menumbuhkan

${ }^{34}$ John Rawls, "The Idea of Public Reason Revisited", Chicago: The University of Chicago Law Review, Vol. 64. No. 3 (1997): 765. kesadaran dan kebutuhan memahami pikiran orang lain dan atau kelompok-kelompok yang mejemuk. mendengar dan menghormati suara dan aspirasi kelompok-kelompok berbeda. Kata kuncinya kemampuan menghargai orang lain (the others) secara adil dan bukan hanya mengandalkan suara terbanyak dalam prosedur demokrasi voting, karena hal itu akan berpotensi pada tirani mayoritas, hal ini disebabkan kebenaran dan kebaikan tidak selalu identik dengan banyaknya pendukung atau besarnya suara. Oleh karena itu dalam demokrasi yang majemuk harus dibangun ruang publik yang rasional tanpa harus terjebak labeling atau stigma yang merendahkan, termasuk terhadap agama/kepercayaan lokal bangsa Nusantara.

\section{DAFTAR PUSTAKA}

An Na'im, AA. Islam dan Negara Sekular Negosiasi Masa Depan Syariah. Bandung: Mizan, 2010.

--------. Dekonstruksi Syariab, Wacana kebebasan Sipil, Hak Asasi Manusia dan Hubungan internasioan dalam Islam. Jogjakarta: LKiS, 1990.

Atkinson, J.M. "Religion and Dialogue, The Construction of an Indonesian Minority Religion". Dalam Rita Smith Kipp dan Susan Rogers (eds), Indonesia Religion in Transition. Tucson: The University of Arizona Press, 1978.

Bagir, Zainal Abidin. Dkk. Pluralisme Kewargaan, Arah Baru Politik Keragaman di Indonesia. Bandung: Mizan-CRCS, 2011.

---------. Mengelola Keberagaman dan Kebebasan Beragama, Sejarah Tradisi dan Advokasi. Bandung: Mizan-CRCS, 2014.

Bahar, Safroedin. Risalah Sidang Badan Penyelidikan Usaba-Usaha Persiapan Kemerdekaan Indonesia (BPUPKI), Panitia Persiapan Kemerdekaan Indonesia (PPKI). Jakarta: Sekretariat Negara RI, 1995.

Banawiratma, J.B. dkk. Dialog Antarumat Beragama, Gagasan dan Praktek di Indonesia. Bandung: Mizan, 2010. 
Bhargava, Rajeev. Political Theory in Introduction. Perison: Oxford Universty, 2014.

Bolland, BJ. Pergumulan Islam Indonesia 1945 1970. Jakarta: Grafiti Pers, 1985.

Dhakidae, Daniel. Cendekiawan dan Kekuasaan dalam Negara Orde Baru. Jakarta: PT. Gramedia Pustaka Utama, 2003.

Geertz, Clifford. The Religion of Java. Chicago and London: The University of Chicago Press, 1960.

Hefner, Robert W. dkk. Remaking Muslim Politics: Pluralism, Contestation, Democratization. Princeton: Princeton University Press, 2005.

Civic Pluralisme Denied? The New Media and Jihadi Violance in Indonesia. Indiana: Indiana University Press, 2003.

Hashemi, Nadar. Islam, Secularisme dan Liberal Demokrasi, Menuju Demokrasi bagi Masyarakat Muslim. Jakarta: Gramedia Pustaka Utama, 2003.

Latif, Yudi. Negara Paripurna, Historisitas, Rasionalitas dan Aktulitas Pancasila. Jakarta: Gramedia Pustaka Utama, 2011.

Maarif, Samsul. Pasang Surut Rekognisi Agama Lelubur dalam Politik Agama di Indonesia. Yogyakarta: Center for Religious and Cross-culture Studies, 2018.

Mulder, Niels. Kebatinan dan Hidup Sehari-bari Orang Jawa: Kelangsungan dan Perubahan Kultural. Jakarta: Gramedia, 1983.

Pals, Daniel L. Eight Theories of Religion, Second Edition. New York: Oxford Univerty Press, 2006.

Rawls, John. "The Idea of Public Reason Revisited". Chicago: The University of Chicago Law Review, Vol. 64. No. 3 (1997).

Saidi, Anas, dkk. Menekuk Agama Membangun Tabta: Kebijakan Agama Orde Baru. Jakarta: Desantara. 2004.

Shachar, Ayelet. "Multicultural Jurisdiction", Law Review, Vol. 35, No. 2 (Summer, 2000).

Sudarto. Religionisasi Indonesia; Sejarah Perjumpaan Agama Lokal dan Agama Pendatang.
Jakarta: PT. Gramedia Pustaka Utama, 2016.

Kondisi Pemenuban Hak Konstitusional Penghayat Kepercayaan Terbadap Tuban Yang Maha Esa. Jakarta: Setara Institute, 2017.

Sutanto, T.S. Merayakan Kebebasan;Bunga Rampai Menyamput 70 Johan Effendi. Jakarta: ICRP dan Kompas, 2013.

Stepan, Alfred. Religion, Democracy, and the Twin Toleration.. Project Muse: John Hopkins University Press, 2000.

Problem of Democratic Transition and Consolidation, Sothern Europe, South America, and Post Comunist Europe. London: John Hopkin University Press, 1996.

The Multiple Secularism of Modern Democratic and Non-Democratic Regimes. New York: Oxford University Press, 2012. 